\title{
Romania:
}

\section{From Institutional to Personal Political Conflict. Mainstream Political Discourse on the Eve of the Refugee Crisis}

\author{
Ioan HOSU \\ Mihnea S. STOICA
}

\begin{abstract}
The article sheds light on the political conflict triggered in Romania by the refugee crisis. In spite of Romania not being amongst the preferred destinations of the refugees, its voice within the European debate was by no means marginal. Nor was the topic peripheral in the discourse of Romanian mainstream political parties, which surprisingly enough - sometimes had staggering opposite views on the issue. Our study taps into the communication patterns of both the media and the politicians representing mainstream political parties, as we aim to understand the political conflict on the issue. Our analysis suggests that political actors did not always respect their ideological views and that their attitudes on the quota system proposed by the European Commission were strategically linked to an agenda not directly related to the refugee crisis.
\end{abstract}

Keywords: Political communication, institutional conflict, refugee crisis, populism, immigration.

\section{Introduction}

The inevitability of conflict in politics has long been acknowledged, acting as an expression of the clashes between public or
Ioan HOSU

Professor, Head of the Communication, Public Relations and Advertising Department, College of Political, Administrative and Communicational Sciences Cluj-Napoca, Romania E-mail: hosu@fspac.ro

\section{Mihnea S. STOICA}

Research Assistant, Communication, Public Relations and Advertising Department, College of Political, Administrative and Communicational Sciences Cluj-Napoca, Romania E-mail: stoica@fspac.ro

\section{Conflict Studies Quarterly} Issue 20, July 2017, pp. 56-66

DOI:10.24193/csq.20.4 Published First Online: 2017/07/3 
- quite frequently - private interests (Lasswell, 1936). Such a reality is mostly visible in liberal democracies, the deliberative dimension of which allows space for disagreement either between various groups of citizens on the one side and the government on the other, or even between decision makers themselves. There is still important lack of consensus in the literature related to the effects on political behavior, with some authors arguing that such conflicting attitudes might actually discourage participation (McClurg, 2003). Even so, most scholars agree on the benefits of democratic political conflict, which approximates a competition for the best arguments and ideas. As history has shown, the European Union is nothing short of political conflict, which seems to have developed into a two-fold tension over its identity. On the one hand, there is the conflict between those who believe the EU is a historical success and those who think the European project is a political failure. And on the other hand, there are sometimes significant tensions between the views on how the EU should further its integration process, which is rather considered to be an extension of domestic politics (Laffan, 1996).

It was not long after its creation that the European Union became an openly contested arena for various political actors who expressed their dissatisfaction with its integration process. The debate about the political survival of the European construction is all but new, having had experienced periods of greater and lower intensity depending on the historical developments of the time. The recent economic depression has greatly affected yet again the political debate about the European Union, with parties embracing a populist rhetoric having emerged as important political actors both as a result of national elections and of European elections. The following chapter of our paper also taps into the development of this political movement. Euroscepticism has come to dominate the public agenda ever since, emerging from the fringes of the political spectrum and arriving as an unavoidable topic for mainstream political parties as well. This process of political contagion is very much related to issue ownership and topic saliency, with two fundamental effects: it aided the visibility (and eventual success) of various niche parties, and it simultaneously altered the discourse of mainstream parties (Meguid, 2005) forcing them to take public position on one side of the debate or the other. Another direction engraving the European debate was identified as coming from Occidentalism, a reaction to Western ideology, splendidly described by Ian Buruma and AvishaiMargalit in their book entitled Occidentalism - A short History of Anti-Westernism (2003). The book has become a reference text for scholars interested in understanding the origins and the development of the anti-Western stances.

It is in this context that migration has developed into being an important source of political ammunition feeding what we previously called the two-fold conflict on the European project. The political space picked up this rhetoric through the migrationdevelopment nexus, a theory that has seldom been questioned ever since it was initially formulated after World War II (Haruța, 2016). Moreover, the rising intensity of the intercultural communication that migration involves has prompted the need for a re- 
negotiation of identities (Hosu, 2015), an act that quite a number of European citizens deem unacceptable.

\section{The refugee crisis as a turning point in the European ideological conflict}

The refugee crisis ranks high on the agenda of today's political debate, be it on a national or on a supranational level being directly related to the phenomenon of migration. Such a situation only counts as a typical effect if we acknowledge that throughout the post-war history of Europe, few other phenomena have managed to exert so much influence on the political debate as migration (Messina, 2007). Therefore, it is only natural that the refugee crisis has developed into an important source of political conflict. The second wave of immigration to Western Europe has disbanded altogether the idea that foreign workers recruited after the Second World War would not settle permanently. Multicultural and multiracial societies have therefore started to become an everyday reality, which in some cases has generated resentment against the newcomers, an attitude that became more visible than ever during the oil crisis of the 1970s and then flourished after the 90's, once Eastern Europe became an important source of immigration towards the West. Ethnicity and sociocultural differences arrived at the point of drawing even violent political cleavages, becoming hinge points for political movements that championed xenophobia and racism. Protecting national values and the so-called traditional way of life has progressively become a major topic, with some political actors embracing a new type of cultural nativism that proved to be unexpectedly popular amongst part of the electorate (Betz, 2003).

This new political rhetoric identified the state as the main culprit for tensions between part of the majority on the one side and the new minorities on the other, thus raising skepticism vis-à-vis the capacity of national institutions - and later on of the European ones - to deal with this new reality. Such an attitude has been an ideological trait primarily of the right side of the political spectrum than of the left. The electoral victories of right-wing populist parties, promoters of a strong nationalist appeal, have remained a clear expression that ethnic differences within the borders of one state are considered to be unbearable by part of its nationals. As such, once acknowledged, the unaccommodating cultural differences have been perceived as a managerial failure of state institutions. In the eyes of those who see their way of life threatened by this new reality, the manager that is to be blamed for the status quo is the state, an entity perceived to put democracy as a system in danger. And dissatisfaction with national policies immediately determines dissatisfaction with the European Union (McLaren, 2005), an attitude amongst the electorate that was politically capitalized especially by populist parties. The economic crisis of 2008 acted as a momentum for most of the populist far right parties, which saw their electoral support rejuvenate in many European countries. This, however, was not the case in Romania, where Greater Romania 
Party (PRM), renowned for its populist and ultranationalist rhetoric, lost all of its seats in the Romanian Parliament and subsequently in the European Parliament during the elections of 2014. Even so, the recent EU parliamentary elections brought forward many new, or older but revitalized, populist parties in the European legislative based in Brussels, which currently hosts two populist far right political groups: the group entitled Europe of Freedom and Direct Democracy, founded by Nigel Farage (former leader of the UKIP) and Europe of Nations and Freedom, lead by Marine Le Pen (of the French Front National) and Marcel de Graaf (of the Dutch Partij Voor de Vrijheid). The short-lived parliamentary group entitled Identity, Tradition, Sovereignty only proves that it is very difficult for such parties to cooperate, which makes one wonder how long the above-mentioned groups will be able to survive politically (Duerr, 2015). However, the great potential of political conflict - which one could call the pathology of "political diabetes" (given the lack of capacity to coagulate into a coherent political entity)does not influence the way the electorate perceives such parties.

Given the political developments that span well over two decades, the number of scholarly work dedicated to the evolution of the populist far right has grown considerably, tackling both their impact on the political system and their influence over the process of policy-making. The theory of the contagion from the right is credited with explaining why mainstream parties sometimes exhibit the tendency of adapting to the discourse of the far right and not vice-versa (Norris, 2005; Bale et al., 2010). And reality has shown that far-right populists cast their influence not only on the right flank of the party spectrum, but also on the left. Contemporary populism puts to the forefront the new issues of identity, legitimacy and political order that are now a priority in the European public debate. The politics of identity is currently a salient topic, having been generated by the uncertainty in respect to the balance between national, local, regional and European identities (Laffan, 1996).

In the context of the current refugee crisis, the importance of understanding such political organizations resides in the fact that most of them are also known as one-issue parties, immigration being the preferred topic to win the sympathy of the electorate. These so-called "challenger parties" build their rhetoric against the issue of immigration, the effects of which have triggered insecurity and fear of the "otherness" in the minds of a significant part of the electorate. Some studies have shown that there is quite a strong correlation between the levels of immigration and support for populist parties (Knigge, 1998; Golder, 2003). Therefore, exclusion seems to be the major rhetorical element of the populist far right, which militates (sometimes violently) against the status quo on immigration. Such parties frequently use a strong nationalist rhetoric to manifest their opposition to multiculturalism and to denounce diversity under most of its forms (Betz, 2015). Moreover, fueled by the effects of the economic crisis, welfare chauvinism has become a defining aspect of the right-wing populist discourse, which claims that social welfare should be available only for those who share the same ethnic 
background with the majority of the people (Taggart, 2000). Immigrants are portrayed as competitors over scarce resources, with populists arguing that their presence does nothing but to contribute to the high unemployment rates and accusing them of "stealing jobs" (Rydgren, 2013).

Studies so far have shown that important waves of immigration (such as the one in 2015) can generate messages with a certain degree of populism, sometimes visible even in the discourse of mainstream parties, usually through contagion from smaller, more radical political actors. Considered to be a strategy consolidated around the idea of exclusion, especially through anti-elitism and scapegoating, populism can easily fuel anti-immigrant sentiments. In explaining its success, many scholars (amongst which Knigge in 1998 and Golder in 2003), identified quite a strong correlation between high levels of immigration and support for the populist rhetoric. Jason Matthew Smith (2010) formulated the same hypothesis and added that increasing crime rates associated with immigration have benefited populism. The situation is especially sensible for Romania, where the party system remained in dire need of ideological clarifications especially after the 2014 presidential elections, the results of which have taken aback virtually all politicians. Ever since, Romania's two dominant parties appear to have been confronted mostly with logistical issues either at the top or at the bottom of the party structures, such activities taking precedence over ideology.

In Romania, the recent political developments (which culminated with the presidential elections of 2014 that were surprisingly won by the candidate of the liberal opposition) have transformed the political system into one approximating a two-party system, with the liberals (PNL) on the right and the social democrats (PSD) on the left of the political spectrum. The transformation is even more spectacular as the political environment was characterized by an inflation of political parties immediately after the fall of the communist regime in 1990. Ever since, and until 2008, far right populists scored very important electoral gains - amongst which in 2000, when their leader competed for president of the Republic (and eventually lost), but making it to the second round of the presidential elections. However, in Romania, the "usual suspects" - as populist far right parties are sometimes referred to, have succumbed due to their lack of credibility (Stoica, 2016). Our analysis seeks to understand whether the disappearance of far right political parties have also meant an absence of the anti-immigrant rhetoric.

\section{The refugee crisis reflected in Romania}

As was the case in all European states, the refugee crisis attracted much of the attention of the national press. In little less than 7 months, Agerpres (the major Romanian news agency) dedicated 2381 news entries to the topic of the refugee crisis, starting from the $9^{\text {th }}$ of September 2015 until the $30^{\text {th }}$ of March 2016. We considered the $9^{\text {th }}$ of September as a starting point for our study given the fact that it was the day the European Commission 
issued the proposal for the regulation that established the quotas for refugees that were to be distributed to each European state through the relocation mechanism. The national news agency dedicated quite an important space to the information, the quote of the day having been reserved for Jean-Claude Juncker, President of the European Commission, who famously declared that day: "We are not in a good state. There is a lack of Europe in the EU and there is a lack of union in this EU". Despite the fact that the agency has clearly considered the news coming from Brussels as an important event, with major relevance for Romania, the article about the quotas ranked only $4^{\text {th }}$ in the interests of the online readers ( 911 hits), most of which turned their attention to the news about the decision of the Government to rise the minimum salary in the state sector. The proximity of the economic issue in the interests of the readers constitutes the main explanation element. Table 1 (below) shows the ranking of the news entries and the differences in the number of viewers:

Table 1: Number of readers per news entry on the $9^{\text {th }}$ of September 2015.

\begin{tabular}{cc}
\hline Rank & Number of readers \\
\hline$\# 1$ & 4731 \\
$\# 2$ & 1592 \\
$\# 3$ & 1089 \\
$\# 4$ & $\mathbf{9 1 1}$ \\
\hline
\end{tabular}

In bold, the newson the quotas proposed by the European Commission.

The first official reaction to the document issued by the European Commission came the same day from the Romanian Minister of Foreign Affairs, who declared that the Government would closely analyze the proposal. "The position that both the Prime Minister and the President of Romania have expressed is that of preferring a system of voluntary, and not mandatory quotas. Any proposal of numbers from the Commission will be subject to a process of internal inter-institutional analysis and negotiations between Member States" was what Minister Bogdan Aurescu has declared the same day during a speech in the Chamber of Deputies. The statement of the Minister shows that there is a unitary view of the two highest state officials related to the position of Romania. This situation, however, quickly suffered radical changes. The next day, Agerpres quoted the President stating that Romania will not enroll in the system of mandatory quotas and the Minister of Foreign Affairs declaring that there are no sanctions if a state does not follow the quotas system.

The table below mirrors the shifting positions related to the refugee crisis of the two major political actors in Romania (President Klaus Iohannis and Prime Minister Victor Ponta), as reflected in the news articles of the national press agency. We have also 
added an additional column representing important national third party actors that have positioned themselves one way or the other vis-à-vis the crisis. The period taken into consideration was between the $9^{\text {th }}$ of September and the $4^{\text {th }}$ of November, the latter date representing the day Prime Minister Ponta resigned due to street protests related to a severe accident in Bucharest that caused the death of tens of young people. Given the political tension between the two major institutional actors, we believe this time period reflects best the positions of the two.

Table 2: The positions of the President of Romania, the Prime Minister and relevant national third parties related to the EU solutions proposed to solving the refugee crisis ( $9^{\text {th }}$ of September $-4^{\text {th }}$ of November 2015)

\begin{tabular}{cccc}
\hline Date & President & Prime Minister & Third party \\
\hline 10.09 & - & - & \\
12.09 & & - & \\
14.09 & & + & $-(\mathrm{TB})^{*}$ \\
15.09 & & + & \\
16.09 & - & - & \\
17.09 & + & - & $+(\mathrm{BNR})$ \\
23.09 & & & $-(\mathrm{TB})$ \\
24.09 & + & & \\
08.10 & + & - & $-(\mathrm{AB})$ \\
13.10 & & & \\
24.10 & & & \\
27.10 & + & & \\
30.10. & & & \\
\hline
\end{tabular}

*TB = Traian Băsescu (former President of Romania: 2004-2014); BNR = Official of the National Bank of Romania; $A B=$ Ana Blandiana (one of the major contemporary poets of Romania, renown public figure).

The attitude of the two major political actors in Romania have quite radically changed over the course of the two months, ending with the resignation of Prime Minister Victor Ponta - a political decision which put an end to the tensions that have been growing ever since the two competed in the presidential elections of 2014. An important date that marked the shift in their attitudes was the $23^{\text {rd }}$ of September, when President Iohannis represented Romania at the European Council in Brussels. Prime Minister Ponta expressed his skepticism that President Iohannis would be able to negotiate anything in the benefit of Romania, having declared that Iohannis "came back [to Romania] with the position of Europe [on the refugee quotas], not that of ours". Moreover, the Prime Minister expressed his hope that "certain things could have still been negotiated" and that during the meeting in Brussels the President should have stressed the poor logis- 
tical capacity of Romania to both host and integrate the refugees. On the other hand, coming back from Brussels, President Iohannis declared that Romania would allocate an extra 300.000 EUR for food programs for the refugees, in total contrast with his statement from a week before his visit, when he declared that "in the EU problems can only be solved through open dialogue and agreement", and "not in a bureaucratic manner". The table above reflects the fact that despite having expressed an identical point of view on the matter at the beginning - namely against the refugee quotas, the views of the President and of the Prime Minister significantly disengaged from one another, with Iohannis arriving at a positive attitude regarding the decision taken in Brussels and Ponta ending his mandate with a view that Romania should be more of a hardliner (alongside Bulgaria and Serbia) in imposing its point of view. In fact, Ponta praised Poland for its negotiating skills with the European Union on this issue. The attitudes of the two major actors leave doubts whether they have been strictly policy-related, or if their strained political relationship also had an influence.

We also included the most significant national third parties that had their opinions reflected in the news flow of the national agency. Considering they could have also contributed to shaping the public opinion on the issue, we have identified three such main third parties that had their say on the matter during the period we analyzed. The most vocal was former president Traian Băsescu, whose aim was to grow the visibility of his newly founded party; his attitude was totally against the refugees, having declared that Romania would commit a grave mistake if it would accept the quotas. Another interesting third party was the National Bank of Romania, the representatives of which declared that the refugees should be seen as a potential new labor force of the country. Lastly, there was the intervention of Ana Blandiana, a famous Romanian poet and a very active militant for democratic reforms, especially during the transition period that followed the fall of the communist regime; the poet was quoted by Agerpres, on the $30^{\text {th }}$ of October: "Should Europe relinquish its culture, it will relinquish its identity as well".

Highly personalized political conflicts are anything but new for the Romanian political scene, a trait that has managed to hold a strong grip on the decision-making process over the last decades, in spite of the significant democratic developments. Moreover, such a situation seems to be rather common for post-communist European countries, where the expectation of achieving democratic changes would primarily rest on individuals with a certain degree of national notoriety, mostly renowned for their opposition to the former dictatorial regimes. Therefore, partisanship would chiefly hinge on faces rather than on specific ideologies, a reflex that keeps on marking policy-making ever since. The existence of a variety of centers of intensely personalized politics triggered the formation of adversarial elites that would systematically engage into time-consuming and counter-productive disputes. Slovakia represents yet another example of how "personalist politics" has marked democratic development and economic recovery after the collapse of the communist regime and the dissolution of the joint Czech-Slovak 
state in 1992. Making and breaking governmental coalitions based on personal sympathies worked as a common denominator for many post-communist countries, a feature that weakened party systems and frequently lead to the failure of Prime Minister and President cohabitation(Leff, 1996).While in Western Europe cohabitation was designed as a means for ensuring the smooth functioning of the government amid political competition between those in power (Knapp\&Wright, 2006), the same mechanism proved to be less efficient in Eastern Europe, where power-sharing lead to the exacerbation of political hostility.

The existence of long-standing social cleavages and at least a mild form of party identity are considered to represent prerequisites for avoiding situations in which personality politics dominates national political systems. However, communism has greatly contributed to leveling social and political identities, by changing political cultures alongside competition incentives, with rewards being given on an individual rather than on a collective level (Whitefield, 1993). Therefore, the articulation of interests in Eastern Europe does not follow the pattern of Western European political competition. The highly divisive issue of the path towards democracy also contributed to the emergence of deeply conflicting views that were assumed by individuals rather than by parties. Personal enmities were now shaping political negotiations, and commitment for democracy was strongly related to public figures that manifested their opposition against elites who either represented at one point or who at least had strong ties with the former communist party (Ewans\& Whitefield, 1993).

Therefore, the development of party competition in Romania after the fall of the communist regime seemed to resemble more of a personal than an ideological conflict, with politicians looking at costs and benefits on the short term; the refugee crisis offered yet another conclusive example in this sense. The rapidly shifting points of view over the quotas, unsanctioned by the electorate, suggest that ideological orientations are still very thin and ill-defined, allowing ample space for politicians to develop a populist rhetoric that would appeal to the national sentiment of a larger segment of the population. An explanation might be related to how politicians react in cases of humanitarian crises - amongst which the refugee crisis - building their media discourse around the imaginings of national identity, feeding on the fear of the unknown "other" (Gale, 2004).

\section{Conclusions}

The conflicting governmental views on the refugee quotas were very much influenced by internal political disagreements between the President of the republic and the Prime Minister at the time, the latter having been the competitor of the President in the 2014 elections. The internal political competition has therefore influenced the mainstream political views on the position of Romania and has sometimes generated ambiguity. In studying the attitudes of the two political actors mentioned above, we have analyzed 
the news articles available on the website of Agerpres, as it represents the main source of information for all other news websites or printed newspapers on many topics, amongst which politics.

Specifically on this issue, the media discourse in Romania reflected the existence of an unjustified form of islamophobia that tried to artificially grow intolerant attitudes by mobilizing nationalist passions in the absence of a background that would offer social or at least historical explanations (Pop, 2016).The study also sheds light upon the ideological characteristics of the political discourse, which at least in this case had very little to do with the traditional left-right cleavage or with the progressive-conservative one. We would have expected the Prime Minister to show more openness towards the relocation mechanism, given the fact that he represented a left-wing party. However, this was not the case. On the other hand, the expectation regarding the President would have been that of a rather conservative attitude, given the fact that he was - before taking up his mandate - the leader of the largest right-wing party in Romania. Despite all this, their attitudes were entirely counter-intuitive reported to their ideological affiliation. The study also confirms that when parties representing the "usual suspects" of populism disappear, one should not take for granted that the anti-immigration discourse fades away completely (Hayton, 2010).

\section{References}

1. Bale, T., Krouwel, A., Green-Pedersen, C., Sitter, N.\& Luther, K. R. (2010). If You Can't Beat Them, Join Them? Explaining Social Democratic Responses to the Challenge from the Populist Radical Right in Western Europe. Political Studies, 58, 410-26.

2. Betz, H.-G. (2003). Xenophobia, Identity Politics and Exclusionary Populism in Western Europe. Socialist Register, 193-206.

3. Betz, H.-G. (2015). Mosques, Minarets, Burqas and Other Essential Threats: The Populist Right's Campaign in Western Europe. In Wodak, R., KhosraviNik, M. \& Mral, B. (Eds.), Right-Wing Populism in Europe. Politics and Discourse (pp. 71-88) London: Bloomsbury Academic.

4. Buruma, I., Margalit, A. (2004). Occidentalism: The West in the Eyes of its Enemies. Penguin: New York.

5. Duerr, G. (2015). Identity, Tradition, Sovereignty. The Transnational Linkages of Radical Nationalist Political Parties in the European Union. In Simpson, P.A., Druxes, H. (Eds.), Digital Media Strategies of the Far Right in Europe and the United States (pp. 105-122). London: Lexington Books.

6. Evans, G., Whitefield, S. (1993). Identifying the Bases of Party Competition in Eastern Europe. British Journal of Political Science, 23, pp. 521-548.

7. Gale, P. (2004). "The Refugee Crisis and Fear. Populist Politics and Media Discourse". Journal of Sociology, 40 (4): 321-340.

8. Golder, M. (2003). "Explaining Variation in the Success of the Extreme Right Parties in Western Europe". Comparative Political Studies, 36, 432-466. 
9. Haruța,C.(2017).”Dinamica Relației dintre Migrațieși Dezvoltare.PerspectiveasupraCazului Republicii Moldova". RevistaTransilvană de Științe Administrative, 2 (39): 88-112.

10. Hayton, R. (2010). Towards the Mainstream? UKIP and the 2009 Elections to the European Parliament. Politics, 30 (1), 26-35.

11. Hosu, R. (2015). "Equality of Religious Freedom? The Indiana RFRA. Some Media Representations". Transylvanian Review of Administrative Sciences, 45E: 76-96.

12. Knapp, A., \& Wright, V. (2006). The government and politics of France. Routledge.

13. Knigge, P. (1998). The ecological correlates of Right-Wing Extremism in Western Europe. European Journal of Political Research, 34, 249-279.

14. Laffan, B. (1996). The Politics of Identify and Political Order in Europe. Journal of Common Market Studies, 34, 81-102.

15. Lasswell, Harold (1936). Politics: Who Gets What, When, How. New York: McGraw-Hill.

16. Leff, C.S. (1996). "Dysfunctional Democratization?: Institutional Conflict in Post-Communist Slovakia." Problems of Post-Communism 43 (5): 36-50.

17. McClurg, Scott (2003). "Social Networks and Political Participation: The Role of Social Interaction in Explaining Political Participation". Political Research Quarterly 56(4): 448-64.

18. McLaren, L. (2005). Explaining Mass-Level Euroskepticism: Identity, Interests, and Institutional Distrust (working paper, Amsterdam).

19. Meguid, B. (2005). "Competition Between Unequals: The Role of Mainstream Party Strategy in Niche Party Success", American Political Science Review, 99(3): 347-359.

20. Messina, A. (2007). The Logics and Politics of Post-WWII Migration to Western Europe. Cambridge: Cambridge University Press.

21. Norris, P. (2005). Radical-right: Voters and Parties in the Electoral Market. Cambridge: Cambridge University Press.

22. Pop, D. (2016). Misrepresentation of Muslims and Islamophobic public discourses in recent Romanian media narratives. Journal for the Study of Religions and Ideologies, 15(44): 33-51.

23. Rydgren, J. \& Ruth, P. (2013). Contextual explanations of radical right-wing support in Sweden: socioeconomic marginalization, group threat, and the halo effect. Ethnic and Racial Studies, 36(4), 711-728.

24. Smith, K. (2010). Does Crime Pay? Issue Ownership, Political Opportunity, and the Populist Right in Western Europe. Comparative Political Studies, 43, 1471-1498.

25. Stoica, M. (2016). The Turning Fortunes of Romania's Far Right. The Rise and Fall of Greater Romania Party. In Fielitz, M. \& Laloire, L. L. (Eds.), Trouble on the Far Right. Contemporary Right-Wing Strategies and Practices in Europe, Bielefeld: Transcript Verlag.

26. Taggart, P. (2000). Populism. Buckingham: Open University Press.

27. Whitefield, S. (1993). Industrial Power and the Soviet State. Oxford: Oxford University Press. 